\title{
PELATIHAN PEMBUATAN VIDEO PEMBELAJARAN BERBASIS POWTOON SEBAGAI ALTERNATIF MEDIA PEMBELAJARAN PADA GURU SMP-TQ MU'ADZ BIN JABAL KENDARI
}

\author{
Amiruddin Takda1, La Tahang², Luh Sukariasih ${ }^{3}$, La Sahara ${ }^{4}$, La Ode Nursalam ${ }^{5}$ \\ Universitas Halu Oleo $1,2,3,4,5$ \\ E-mail: amiruddintakda@uho.ac.id1', tahang08@gmail.com², luh.sukariasih@uho.ac.id², \\ saharaku1977@yahoo.co.id ${ }^{4}$, laodenursalam77@gmail.com ${ }^{5}$
}

\author{
Article History: \\ Received: 16-02-2021 \\ Revised: 19-02-2021 \\ Accepted: 20-02-2021
}

Keywords: Powtoon; Learning video; Learning media; Technology.

Kata Kunci: Powtoon; Video pembelajaran; Media pembelajaran; teknologi.

\begin{abstract}
Activities seek to improve the awareness and information of teachers about the role of educational media in Junior High School learning activities. Furthermore, this curriculum also teaches SMP TQ-Mu'adz Bin Jabal teachers to use the Powtoon technology to design and render instructional videos. Increasing teacher imagination in the creation and use of video learning media is the specific goal to be accomplished, so that science learning in schools can be more contextual. The method used in implementing this Community Service is counselling, training, and question and answer methods. This activity begins with observations in schools and related institutions/agencies in the first week, followed by core activities at SMP TQ-Mu'adz Bin Jabal Kendari. From the results of the dedication, it was found that: (1). This activity has been able to increase teacher knowledge about the urgency of instructional media and the development of forms of instructional media, especially those related to technological developments; (2) This activity has been able to improve the ability of teachers to operate computers or laptops, including in making online-based learning videos that are integrated into Powtoon.
\end{abstract}

Abstrak: Kegiatan berupaya meningkatkan kesadaran dan informasi guru tentang peran media pendidikan dalam kegiatan pembelajaran Sekolah Menengah Pertama. Lebih lanjut, kurikulum ini juga mengajarkan para guru SMP TQ-Mu'adz Bin Jabal untuk menggunakan teknologi Powtoon untuk mendesain dan membuat video pembelajaran. Peningkatan imajinasi guru dalam pembuatan dan penggunaan media pembelajaran video merupakan tujuan khusus yang ingin dicapai, sehingga pembelajaran IPA di sekolah dapat lebih kontekstual. Metode yang digunakan dalam pelaksanaan Pengabdian ini berupa metode penyuluhan, pelatihan, dan tanya jawab. Adapun kegiatan ini dimulai dengan observasi di sekolah dan lembaga/instansi terkait pada minggu pertama.Dilanjutkan dengan kegiatan inti di SMP TQ-Mu'adz Bin Jabal Kendari. Dari hasil pengabdian diperoleh bahwa: (1). Kegiatan ini telah mampu meningkatkan pengetahuan guru tentang pentingnya media pembelajaran serta perkembangan bentuk-bentuk media pembelajaran khususnya berkaitan dengan perkembangan teknologi; (2) Kegiatan ini telah mampu meningkatkan kemampuan guru dalam mengoperasikan komputer atau laptop diantaranya dalam membuat videp pembelajaran berbasis online yang teritegrasi kedalam Powtoon. 


\section{Pendahuluan}

Pendidikan merupakan kedudukan dengan dimensi untuk mencerdaskan bangsa dan membangun masyarakat[1]. Pertumbuhan siswa dan keyakinan, kesadaran dan sikap masyarakat menunjukkan hubungan antara pendidikan dan tuntutan perubahan. Dalam rangka membantu peserta didik menggali, menemukan, mempelajari, menghayati dan menghayati nilai-nilai yang berguna, baik bagi diri sendiri, bangsa dan bangsa secara keseluruhan, pendidikan lebih menitikberatkan pada peserta didik dalam proses pembelajaran. Dalam rangka meningkatkan mutu pendidikan dan menciptakan sumber daya manusia yang berkualitas, guru merupakan salah satu faktor penentu karena guru merupakan garda terdepan yang berhadapan dan berkomunikasi dengan siswa dalam proses pembelajaran [2]. Kualitas pendidikan yang kuat dengan guru terlatih apabila guru mempunyai kapasitas dan kompetensi yang sesuai[3].

Salah satu faktor kunci yang mempengaruhi keberhasilan guru adalah pertumbuhan profesional yang berkelanjutan. Pengalaman negara lain mendukung fakta bahwa partisipasi dalam seminar, kursus dan pelatihan juga berkontribusi pada peningkatan substansial dalam kualitas guru[4]. Gagasan belajar menuntut pergeseran posisi guru. Guru lebih menyukai transformator dalam pengertian konvensional, artinya guru hanya berprofesi sebagai guru. Dengan menggunakan kontak langsung untuk mengkomunikasikan pesan, tren ini membuat siswa kurang tertarik untuk menerima informasi saja, seperti contoh gelas siap diisi air. Keadaan ini tidak sejalan dengan prinsip belajar. Pembelajaran memandang peserta didik sebagai warga negara yang berhasil, dengan keterampilan dan kapasitas yang perlu dieksplorasi secara optimal. Pembelajaran sering kali mencakup peran yang lebih luas bagi guru, selain melihat peran aktif siswa yang esensial dalam pembelajaran. Dengan kata lain, mampu merencanakan pembelajaran yang baik, termasuk merancang media pembelajaran, merupakan salah satu tugas guru sebagai desainer pembelajaran..

Akibat dari kegiatan pembelajaran ini, perkembangan pengalaman belajar yang bermakna atau pengalaman belajar yang bermakna tidak lepas dari peran media, terutama dari posisi dan fungsinya. Media pembelajaran bermanfaat untuk melengkapi, menopang bahkan meningkatkan kualitas dan proses pembelajaran, menumbuhkan hasil belajar, aktivitas dan motivasi belajar siswa[5].

Media pembelajaran merupakan salah satu komponen yang berperan pada tingkat satuan pendidikan dalam melaksanakan proses pembelajara[6]. Semakin baik dan menarik media yang digunakan dalam proses pembelajaran maka akan semakin mudah dalam mencapai tujuan pembelajaran begitu relevansi media pembelajaran dapat dilihat dari pengalaman pembelajaran yang terjadi [7]. Tidak hanya di jenjang pendidikan SD, SMP dan perguruan tinggi, media pembelajaran digunakan. Ini juga dapat dilihat pada tingkat pendidikan anak usia dini. Media yang diakui dalam pembelajaran sangat beragam. Musfiqqon [8] membagi media menjadi tiga bentuk, 
yaitu media visual, audio dan kinestetik. Jenis gambar, diagram, peta, grafik, kartun, poster, papan flanel boleh jadi media visual. Meskipun media kinestetik dapat didramatisasi, presentasi, permainan, dan simulasi dapat berupa.

Media pembelajaran saat ini sangat banyak macamnya. Apalagi media pembelajaran berkembang dan secara bertahap membantu dalam proses pembelajaran seiring dengan berkembangnya teknologi dan multimedia. Media pembelajaran yang memanfaatkan perpaduan gambar, suara atau audio, dan video adalah media pembelajaran berbasis multimedia. Video merupakan salah satu media pembelajaran berbasis multimedia yang dapat digunakan untuk distribusi konten. Konten tersebut ditransmisikan dengan gambar bergerak yang terdiri dari beberapa frame yang diputar atau diatur dan ditampilkan secara bergantian sehingga objek bergerak dapat ditampilkan dalam video. Penggunaan aplikasi pendukung, seperti Powtoon, merupakan salah satu jenis video pembelajaran yang sedang trending. Aplikasi Powtoon adalah aplikasi yang terhubung dengan internet atau aplikasi web online yang dapat menyajikan presentasi atau presentasi materi. Tampilan tersebut berupa video yang menampilkan beberapa animasi yang dapat menarik perhatian siswa. Kholilurrohmi [9]\& Delviana [10] menjelaskan bahwa semua orang, termasuk guru dan siswa, dapat mengakses aplikasi ini dan cara membuat video animasi sangat sederhana karena fitur yang tersedia sangat lengkap, seperti animasi tulisan tangan, animasi kartun, dan lebih hidup efek transisi dan pengaturan garis waktu yang cukup sederhana..

Anda dapat melihat sebagian besar fungsionalitas di satu layar dan dapat menggunakannya dalam proses membuat presentasi atau presentasi. Inilah yang membuat program Powtoon semakin umum digunakan di dunia pendidikan. Adkhar [11] \& Fitriani [12] melaporkan bahwa salah satu kelebihan Powtoon adalah mudah digunakan dan tidak memerlukan keahlian khusus karena langkah yang diambil tidak berbeda dengan memutar video biasa di komputer / laptop, vcd player, atau umumnya. pemutar DVD. Selain itu, pada framework Powtoon sudah terdapat banyak pilihan animasi yang menarik dan lucu, sehingga pengguna tidak perlu lagi membuat animasi[13]. Hasil akhir Powtoon berupa video animasi cukup interaktif sehingga dapat menarik minat siswa didik untuk memperhatikan tayangan tersebut[14].

Dengan adanya perkembangan ilmu pengetahuan dant teknologi, menuntut guru-guru untuk dapat menghadirkan media pembelajaran yang representatif. Melalui program ini, guru akan diperkenalkan tentang pembuatan video pembelajaran dengan menggunakan aplikasi Powtoon. Disamping itu, guru juga akan dilatih dalam merancang dan membuat media pembelajaran video sesuai dengan perencanaan pembelajaran yang telah dibuat oleh guru. Berdasarkan latar belakang permasalahan yang diuraikan di atas, pelaksana program pengabdian masyarakat dilaksanakan di SMP Tahfidzul Qur'an Mu'adz Bin Jabal Kendari dan telah menyepakati persoalan prioritas yang akan diselesaikan melalui program pengabdian masyarakat terbatasnya kemampuan guru dalam membuat video pembelajaran yang interaktif 


\section{Metode}

Kegiatan ini dilakukan di SMP TQ-Mu'adz Bin Jabal Kendari. Peserta Pelatihan adalah guru-guru SMP TQ-Mu'adz Bin Jabal Kendari. Secara umum metode pelaksanaan yang digunakan dalam kegiatan pengabdian kepada masyarakat ini menggunakan metode ceramah, tanya jawab dan diskusi dan pendampingan. Metode ceramah dan diskusi dilakukan secara pertemuan dengan guru-guru mitra untuk menyampaikan materi tentang Teknik pengembangan media pembelajaran.Workshop dilakukan untuk penyusunan pembuatan video pembelajaran. Sebagai tenaga professional, seorang guru dituntut untuk selalu mengembangkan diri sesuai dengan keprofesiannya Pengembangan profesi guru merupakan kegiatan guru dalam rangka menghasilkan sesuatu yang bermanfaat bagi pendidikan.Berdasarkan analisis situasi permasalahan yang dihadapi adalah masalah dalam pembelajaran dimana keterbatasan media pembelajaran di sekolah menjadikan guru dalam mengajar hanya menggunakan model pembelajaran tradisional. Berdasarkan hasil wawancara hanya sedikit guru yang mengajar memanfaatkan media pembelajaran dan jarang guru mengajar menggunakan media audiovisual dalam proses pembelajaran.

\section{Hasil}

Kegiatan pengabdian masyarakat yang bertemakan pelatihana pembuatan video pembelajaran berbasis Powtoon dilaksanakan pada tanggal 30 Desember 2020 bertempat di SMP-TQ Mu'adz Bin Jabal Kota Kendari Sulawesi Tenggara melalui via zoom cloud meeting. Kegiatan pengabdian ini dimaksudkan untuk menyelesaikan permasalahan mitra berkaitan dengan keterbatasan multimedia pembelajaran yang digunakan untuk proses pembelajaran khususnya selama masa pandemic Covid-19. Pengabdian ini dilaksanakan dalam bentuk workshop pembuatan multimedia pembelajaran berbasis Powtoon yang diikut oleh guru SMP-TQ Mu'Adz Bin Jabal. Pada pengabdian ini terfokus pada pendampingan guru guru dalam memanfaatkan teknologi pembelajaran untuk kebutuhan sumber belajar. Luaran yang dihasilkan dari pengabdian masyarakat ini adalah guru dapat membuat media pembelajaran dari Powtoon berupa video pembelajaran. Kegiatan ini telah diikuti oleh 15 orang guru sekolah yang berasal dari SMP-TQ Mu'adz Bin Jabal.

Sebelum kegiatan praktek pembuatan video pembelajaran berbasis Powtoon, kegiatan dimulai dengan materi pengantar, antara lain urgensi media pembelajaran dan presentasi awal fitur Powtoon kepada peserta, sebelum kegiatan realistis pembuatan video pembelajaran berbasis Powtoon. Guna menyegarkan kesadaran guru akan urgensi media dalam pembelajaran, dilakukan latihan presentasi konten dan diskusi. Selain itu, kemajuan teknis melibatkan imajinasi guru untuk menggunakannya, bahkan sebagai media pembelajaran. Media pembelajaran dapat membantu siswa mengembangkan pemahaman dan hasil belajarnya.. 
Jurnal Pengabdian Masyarakat Nusantara Vol. 1, No. 1, Februari, 2021, hal : 8-17, E-ISSN : 2775-734X DOI: https://doi.org/10.35870/jpmn.v1i1.265

Workshop pembuatan video pembeljaran berbasis Powtoon telah dilaksanakan dalam tiga tahapan yaitu pembuatan persentasi, pembuatan video, dan konversi video pembelajaran. Masing-masing kegiatan ini dilakukan dengan mempraktekan secara langsung melalui komputer atau laptop peserta.

\section{A. Tahap pertama}

Pada tahap ini guru diberikan pengetahuan awal mengenai penggunaan Powtoon sebagai media pembelajaran yang terdiri dari vitur, bagian bagian powtoon, cara loggin,pembuatan akun, serta penggunaan mode free pada aplikasi Powtoon . Selanjutnya para guru di damping untuk melakukan loggin berupa pembuatan akun baik secara manual ataupun yang terintegrasi secara langsung melalui akun gmail/account google. Tampilan awal Powtoon disajikan pada Gambar 1.

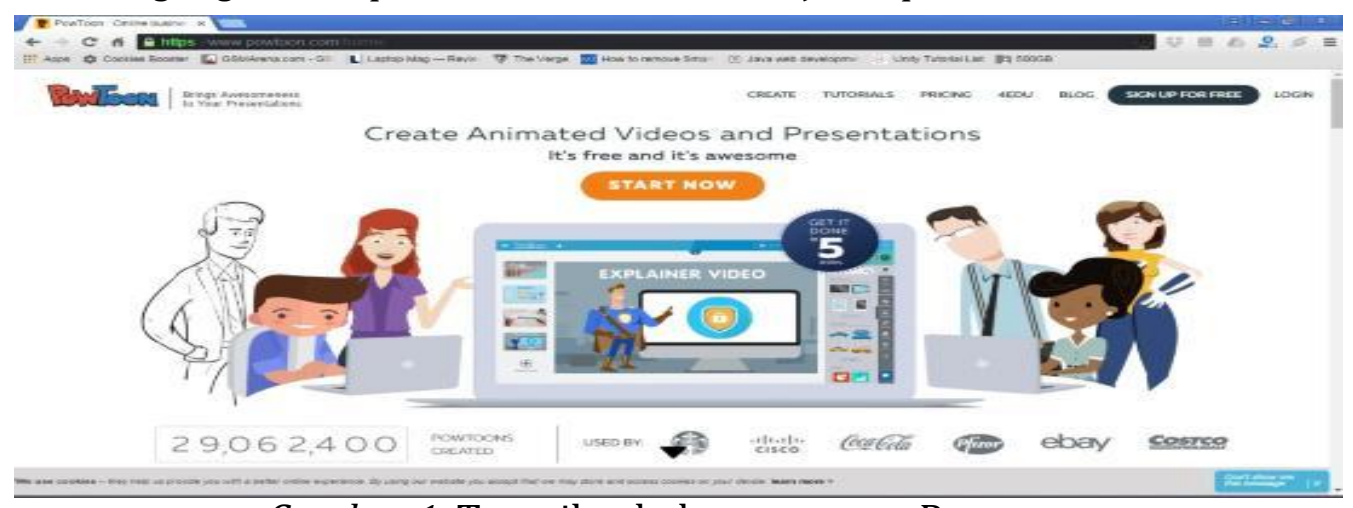

Gambar 1. Tampilan halaman utama Powtoon

B. Tahap kedua

Pada tahap kedua ini tim pengabdian melakukan pendampingan kepada peserta guru SMP-TQ Mu'adz Bin jabal berupa pendampingan pembuatan video pembelajaran berbasis Powtoon. Tim Pengabdian memberikan pendampingan berupa cara menggunakan vitur yang telah tersedia pada laman Powtoon, dimana masing masing guru membuat akun Powtoon dan masuk kedalam laman Powtoon https://www.powtoon.com/account/login/. Pendampingan ini dilaksanakan dalam bentuk online terintegrasi zoom cloud meeting. Aktivitas kegiatan pengabdian disajikan pada Gambar 2 dan Gambar 3.

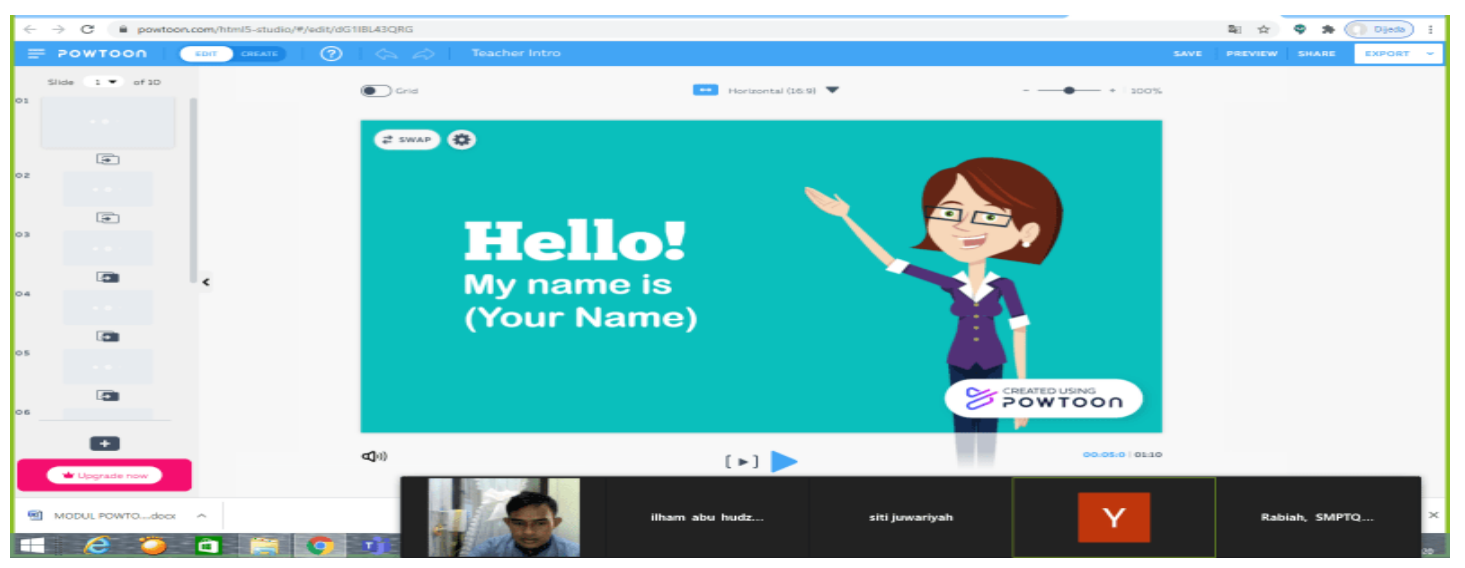


Jurnal Pengabdian Masyarakat Nusantara

\section{Gambar 2. Tim pengabdian memberikan penjelasan awal terkait cara membuat media dengan Powtoon}

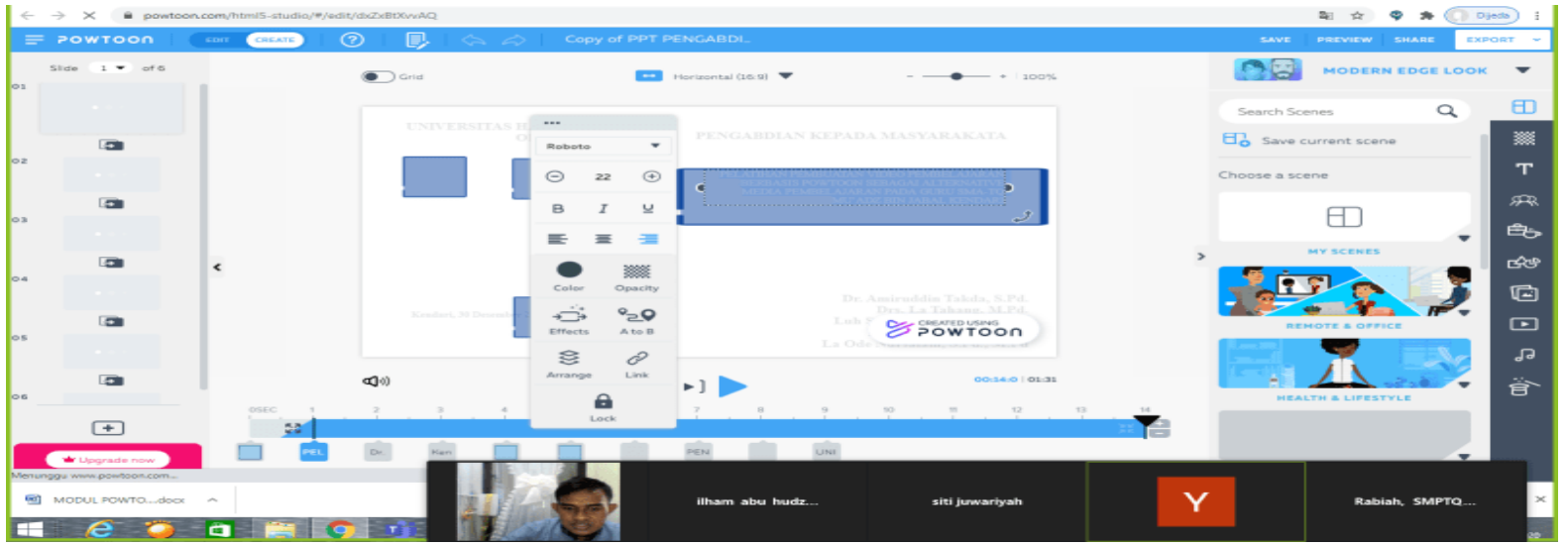

Gambar 3. Tim pengabdian memberikan penjelasan terkait penggunaan masing-masing item pada Powtoon

C. Tahap ketiga

Pada tahap ketiga setalah guru telah berhasil membuat video pembelajaran yang dibuat, selanjutnya tim pengabdian mendampingi guru agar hasil video pembelajaran yang dibuat dapat di unduh dan di publish secara online. Pengunduhan video pembelajaran yang telah dibuat dengan menggunakan Powtoon dilakukan dengan berbagai cara diantaranya di integrasikan ke lama YouTube. Hal ini dikarenakan agar hasil video pembelajaran yang dibuat dapat diakses oleh orang lain dan dapat dijadikan sebagai kebutuh untuk pembelajaran. Apabila video yang dibuat telah berhasil di upload kelaman YouTube, proses selanjutnya adalah mengarahkan peserta atau guru untuk membuka laman savefromnet untuk mengunduh hasil video pembelajaran yang telah dibuat dengan cara memasukkan link Youtube video pembelajaran yang dibuat. Langkah ini disajikan pada Gambar 4.

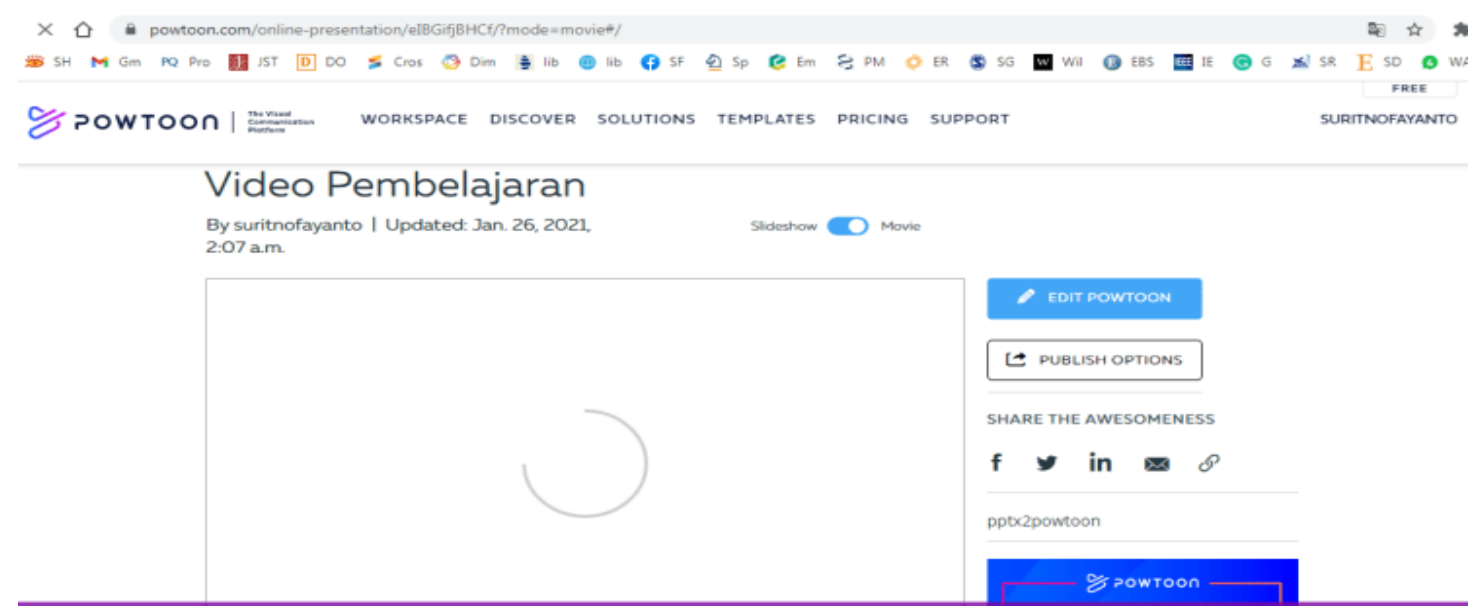

Gambar 4. Proses peng-uploatan melalui via Youtube

Selain melalui laman YouTube, hasil videp pembelajaran yang telah dibuat dapat di convert dalam bentuk slide PPT yang telah tersedia dilaman Powtoon. Hal ini 
Jurnal Pengabdian Masyarakat Nusantara

bertujuan untuk memudahkan guru dalam membuat persentasi yang menarik. Tampilan disajikan pada Gambar 5.

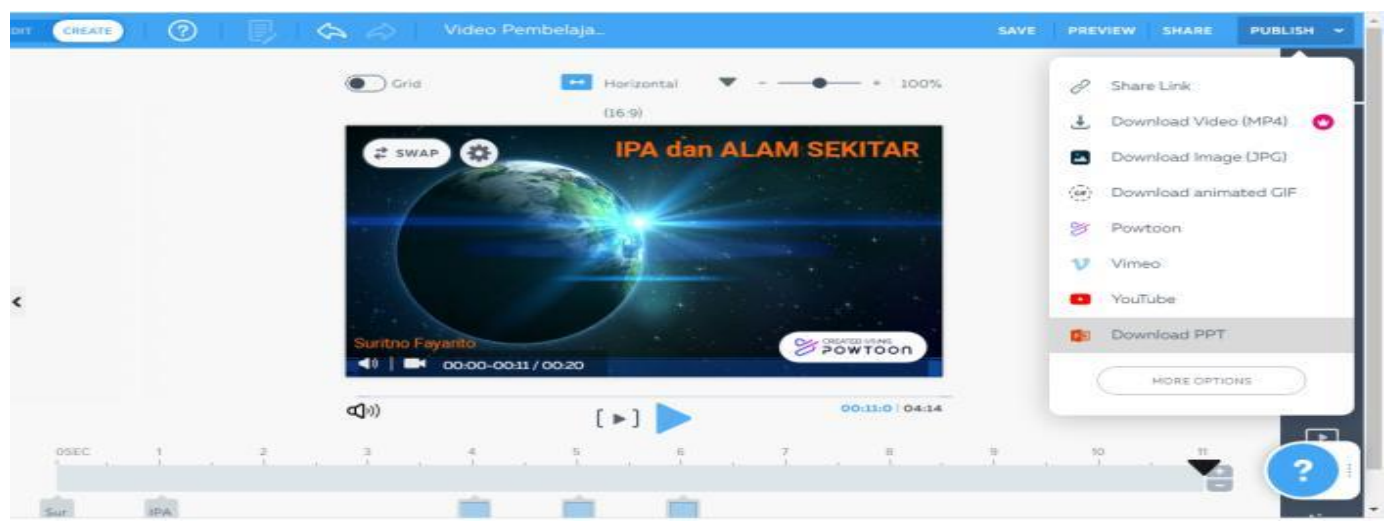

Gambar 5. Proses konversi via PPT

Praktek pembuatan video pembelajaran menggunakan Powtoon dilakukan dengan bantuan instruktur dibantu mahasiswa pelaksana Tim Pengabdian.

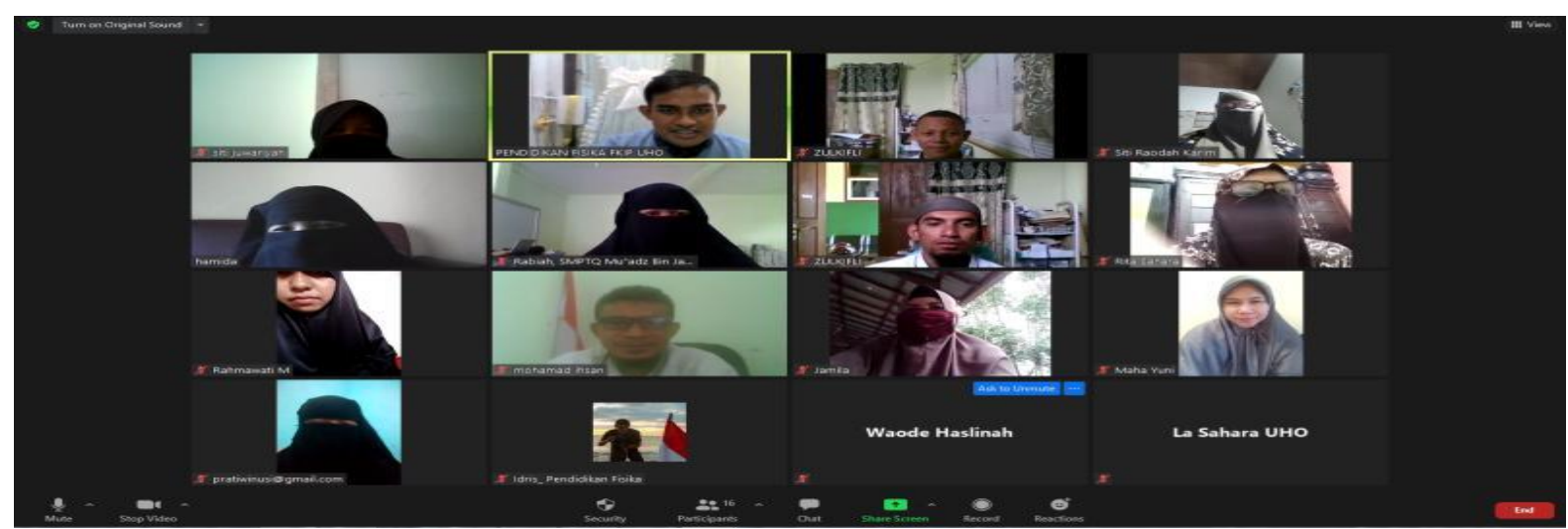

Gambar 6. Kegiatan penutup dari workshop

Hasil penyajian materi, diskusi dan praktek yang telah dilakukan dapat dirumuskan sebagai berikut:

a. Secara umum kegiatan berjalan dengan sangat baik. Guru SMP-TQ Mu'adz Bin Jabal sangat antusias dan serius dengan tahapan materi pelatihan yang diberikan oleh nara sumber:

b. Peserta dalam kegiatan tersebut mengaku bahwa kegiatan ini masih baru dan dapat meningkatkan pemahamannya. Hal tersebut ditunjukkan dengan kontinuitas jumlah peserta yaitu mulai pukul 09.00-11.50 WIB dari awal latihan kegiatan berakhir

c. Beberapa peserta berhasil membuat video pembelajaran menggunakan Powtoon di akhir sesi. Responden yang puas berada dalam posisi untuk membuat produk buatan sendiri;

d. Praktik ini diharapkan menjadi kegiatan berkelanjutan untuk meningkatkan profesionalisme guru dan dianggap sebagai kebutuhan yang harus dipenuhi oleh guru. 


\section{Diskusi}

Hampir semua sekolah mengalami kesulitan, seperti disebutkan di atas, dari temuan evaluasi awal dan wawancara sebelum layanan dilakukan. Seperti yang dikatakan salah satu guru dalam proses wawancara di SMP TQ-Mu'adz Bin Jabal, kendala tersebut ada. Ia mengatakan, alat peraga, peralatan praktik, dan media pembelajaran lain yang dapat digunakan sebagai sarana pembelajaran juga masih kurang. Tanpa bantuan alat peraga atau media pembelajaran yang dapat digunakan sebagai penunjang komponen proses belajar mengajar, pembelajaran yang dilakukan seringkali menggunakan bentuk ceramah.

Sementara itu, kemajuan peralatan teknologi dan komunikasi dapat membantu guru dalam menghadirkan media pembelajaran virtual sebagai media pembelajaran alternatif dalam hal lain. Selain itu media pembelajaran video dapat menarik perhatian dan semangat belajar dari siswa. Berdasarkan permasalahan di atas maka perlu dilakukan kegiatan yang dapat meningkatkan keterampilan guru. Mu'adz Bin Jabal di SMP-TQ dalam pembuatan dan pendistribusian media pembelajaran video berbasis Powtoon.

Akar dari permasalahannya adalah tidak banyak guru yang mampu melakukan kegiatan pengembangan profesionalisme.Rendahnya motivasi dan kemampuan guru dalam mengembangkan media pembelajaran dapat berakibat rendahnya motivasi belajar peserta didik.Hal ini sesuai dengan Purwono et al [15] yang menyatakan bahwa media juga dapat membuat pembelajaran lebih menarik dan menyenangkan. Disisi lain kegiatan workshop, pelatihan tentang teknik pembuatan media pembelajaran juga sehingga kesempatan para guru-guru untuk mengikuti kegiatan pelatihan juga kurang.

Berdasarkan hasil pengabdian banyak guru tertarik menggunakan powtoon, hal ini dibuktikan dengan antusiasme guru menyelesaikan desain video pembelajaran yang dibuat selama workshop berlangsung. Hampir semua guru bertanya mengenai system penggunaan mulai dari cara penggunaan sampai cara mengkoversi di tahap akhir. Antusiasme guru ini dikarenakan penggunaan Powtoon dianggap sebagai media baru dalam pembelajaran. Para guru merasa bahwa Powtoon mempunyai vitur yang menarik, serta dilengkapa dengan berbagai animasi, background, insert video atau pun voice note yang menarik.

Akan tetapi terlebih dari fasilitas tersebut. Ada beberapa kendala yang dihadapi diantara fasilitas internat yang kurang memadai merupakan salah satu faktor. Hal ini dikarenakan internet merupakan penunjang utama dalam pembuatan video pembelajaran berbasis Powtoon. Tanpa internet yang stabil pembuatan video dengan menggunakan Powtoon akan membutuhkan waktu yang cukup lama. Selain ketersedian sumber daya manusia dalam artian bahwa kemampuan guru dalam melek teknologi masih kurang, sehingga para guru harus dibanti step by step untuk dapat menyelesaikan proyek yang diberikan. Terlebih dari itu semua, hasil pengabdian ini memberikan sebuah nilai kebaruan dari penggunaan media pembelajaran, yang selama ini hanya berbasis konvensional. Oleh karena itu, dengan penggunaan perkenalan Powtoon diharapkan menjadi sebuah alternative baru bagi guru guru sebagai media transfer pengetahuan. 


\section{Kesimpulan}

Berdasarkan kegiatan disimpulkan sebagai berikut berdasarkan hasil dan pembahasan workshop video pembelajaran berbasis Powtoon: (1). Kegiatan ini memungkinkan para guru untuk meningkatkan pengetahuannya tentang urgensi media pendidikan dan perkembangan bentuk media pendidikan, khususnya yang berkaitan dengan perkembangan teknologi (2). Kegiatan ini dapat mampu meningkatkan kemampuan guru dalam mengoperasikan komputer atau laptop, termasuk pembuatan video pembelajaran online yang diintegrasikan ke dalam Powtoon.

\section{Pengakuan/Acknowledgements}

Ucapan terima kasih penulis sampai kepada Lembaga Penelitian Dan Pengabdian Kepada Masyarakat Universitas Halu Oleo atas dukungan dalam melakukan pengabdian ini. Penulis tak lupa menyampaikan ucapan terima kasih kepada Kepala Sekolah SMPTQ Mu'adz Bin Jabal atas kesedian waktu serta fasilitas penunjang yang diberikan. Penelitian ini beruh Hibah Pengabdian Mandiri denga Nomor Surat Tugas: 1884/UN29.20/AM/2020.

\section{Daftar Referensi}

[1] F. Alawiyah, "Kebijakan dan Pengembangan Pembangunan Karakter melalui Pendidikan di Indonesia," J. Aspir., vol. 3, no. 1, pp. 87-101, 2012.

[2] A. Efferi, "Model Pendidikan Guru Dalam Meningkatkan Mutu Pendidikan," Qual. J. Pendidik. Islam, vol. 3, no. 2, pp. 237-256, 2015.

[3] L. I. Ahmad, "Konsep Penilaian Kinerja Guru Dan Faktor Yang Mempengaruhinya," Idaarah J. Manaj. Pendidik, vol. 1, no. 1, pp. 133-142, 2017, doi: 10.24252/idaarah.v1i1.4133.

[4] Indrawati, Pengelolaan Pelatihan PCT, DCT, dan Guru Pemandu di KKG/MGMP Program Bermutu. Jakarta: Depdiknas, Dirjen PMPTK, 2009.

[5] G. Abudllah and Yusuf Djafar, "Pelatihan Pembuatan Video Pembelajaran Menggunakan Aplikasi Camtasia Studio Berbasis Powerpoint Bagi Guru-Guru Sekolah Dasar Di Desa Sukamakmur Kecamatan Tolangohula Kabupaten Gorontalo," Gorontalo, 2015. [Online]. Available: https://repository.ung.ac.id/abdi/show/1/894/pelatihan-pembuatan-videopembelajaran-menggunakan-aplikasi-camtasia-studio-berbasis-powerpoint-bagiguru-guru-sekolah-dasar-di-desa-sukamakmur-kecamatan-tolangohulakabupaten-gorontalo.html.

[6] S. Fayanto, M. Misrawati, D. Sulisworo, H. F. N. Istiqomah, and L. Sukariasih, "The Implementation of Multimedia on Physics Learning Based on Direct Instruction Model in The Topic of Light," Indones. J. Learn. Educ. Couns., vol. 1, no. 2, pp. 124132, 2019, doi: 10.31960/ijolec.v1i2.94.

[7] A. Prastowo, Menyusun Rencana Pelaksanaan Pembelajaran (RPP) Tematik Terpadu: Implementasi Kurikulum 2018 Untuk SD/MI. Kencana Publisher, 2017. 
Jurnal Pengabdian Masyarakat Nusantara

[8] H. M. Musfiqon, Pengembangan Media dan Sumber Pembelajaran. Jakarta: Prestasi Pustaka, 2012.

[9] I. Kholilurrohmi, "Efektivitas Penerapan Media Pembelajaran Video Powtoon Pada Mata Pembelajaran Kimia Terhadap Motivasi dan Prestasi Belajar Peserta Didik Kelas X Semeseter 1 SMAN 1 Pler," Universitas Negeri Makassar, 2017.

[10] E. Deliviana, "Aplikasi PowToon Sebagai Media Pembelajaran: Manfaat dan Problematikanya," in Prosiding Seminar Nasiona Dies Natalis Ke-56 Universitas Negeri Makassar, 2017, pp. 1689-1699.

[11] B. I. Adkhar, "Pengembangan Media Video Animasi Pembelajaran Berbasis Powtoon Pada Kelas 2 Mata Pelajaran Ilmu Pengetahuan Alam di SD Labschool UNNES," Universitas Negeri Semarang, 2016.

[12] N. Fitriyani, "Pengembangan Media Pembelajaran Audio-Visual Powtoon Tentang Konsep Diri Dalam Bimbingan Kelompok Untuk Peserta Didik Sekolah Dasar," J. Tunas Bangsa, vol. 6, no. 1, pp. 104-114, 2019.

[13] C. \& N. I. Semaan, "Effect of Using Powtoon on Learning English As a Foreign Language," Int. J. Curr. Res., vol. 10, no. 05, pp. 69262-69265, 2018, [Online]. Available: https://www.journalcra.com/article/effect-using-powtoon-learningenglish-foreign-language.

[14] R. Herawati, D. Sulisworo, and S. Fayanto, "The Development of Learning Videos on PowToon-based Work and Energy Topics to Support Flipped Classroom Learning," IOSR J. Res. Method Educ., vol. 9, no. 4, pp. 51-58, 2019, doi: 10.9790/1959-0904015158.

[15] J. Purnomo, "Penggunaan Media Audio-Visual Pada Mata Pelajaran Ilmu Pengetahuan Alam Di Sekolah Menengah Pertama Negeri," J. Teknol. Pendidik. dan Pembelajaran, vol. 2, no. 2, pp. 127-144, 2014. 